\title{
Ethnic Cleansing, Genocide or Ukrainian-Polish War in Volhynia?
}

\author{
Ivan Katchanovski, Ph.D. \\ School of Political Studies \\ \& Conflict Studies and Human Rights Program \\ University of Ottawa \\ Ottawa, ON \\ K1N 6N5, Canada \\ Tel. 613-407-1295 \\ ikatchan@uottawa.ca
}

Paper prepared for presentation at the Annual Meeting of the American Political Science Association, September 10-13, 2020 


\begin{abstract}
This paper analyzes the mass murder of Poles in Volhynia in Western Ukraine during World War II. The mass murder of Poles by the Ukrainian Insurgent Army (UPA) and the Stepan Bandera faction of the Organization of Ukrainian Nationalists (OUN-B) during the German occupation of Volhynia in 1943 became an important political issue in Poland and Ukraine after the collapse of communism, especially in the last fews years. Previous studies by Polish, Ukrainian, and Western researchers offered different and often divergent theories of this historical event. It is often presented in Ukraine as a Ukrainian-Polish war, in particular, by the Ukrainian Institute of National Memory after the "Euromaidan". The laws and policies adopted by the Maidan governments glorified the far right OUN and the UPA, their leaders and members as national heroes and fighters for the Ukrainian independence. In contrast, the mass murder of Poles in Volhynia is often characterized in Poland as a genocide. The Polish parliament declared in 2016 that the Volhynian massacre constituted a genocide. The research question is whether this mass murder was an ethnic cleansing, genocide, or Ukrainian-Polish war. This study analyzes archival documents from the Branch Archive of the Security Service of Ukraine (SBU), the Central State Archives of Supreme Bodies of Power and Government of Ukraine, the SBU archive in Volyn Region, and the State Archive of Volyn Region, historical studies, and eyewitness accounts in English, Polish, Russian, and Ukrainian languages. It offers an estimate of Polish casualties derived from analysis of Polish, Soviet, and Ukrainian sources and demographic data. This study shows that the mass murder of the Polish minority in Volhynia by the OUN-B, the UPA, and their security service (SB) did not constitute a Ukrainian-Polish war or a genocide of Poles but that it was a part of an ethnic cleansing.
\end{abstract}




\section{The Research Question and Diverging Narratives and Policies}

The mass murder of Poles by the Ukrainian Insurgent Army (UPA) and the Stepan Bandera faction of the Organization of Ukrainian Nationalists (OUN-B) during the Nazi occupation of Volhynia in Western Ukraine in 1943 became an important political issue in Poland and Ukraine after the collapse of communism in these countries (see, for example, Katchanovski, 2015;

Marples, 2010). This mass murder was downplayed in Soviet Ukraine and communist Poland for ideological reasons. First Polish and then Ukrainian historians and politicians started to raise and debate this historical event at the end of the 1980s and the 1990s. Presidents of Ukraine and their Polish counterparts became involved to various extents in dealing with this historical issue.

However, attempts to find a common ground in defining and commemorating the mass murder of Poles in Volhynia and subsequent mass killing of Ukrainians in Poland have not succeeded (see, for instance, Ukraina-Polshcha, 1998-2001).

This study investigates the mass-murder of Poles in Volhynia during World War II.

The research question is whether the mass-murder of Poles in Volhynia during World War II was a Ukrainian-Polish war, ethnic cleansing or genocide. Previous studies by Polish, Ukrainian, and Western researchers suggest different and often divergent theories of this historical event. Basic issues, such as conflict type, its start, perpetrators, and the numbers of casualties are still debated. Many previous studies of the mass murder of Poles in Western Ukraine were conducted in Poland and Ukraine by non-academic researchers and activists. This research was often politicized and based on one-sided or non-corroborated sources.

The study is based on analysis of a variety of archival documents, historical studies, testimonies, in English, Polish, Russian, and Ukrainian languages to ensure its reliability. These 
sources include archival documents from the Branch Archive of the Security Service of Ukraine (HDA SBU), the Central State Archives of Supreme Bodies of Power and Government of Ukraine (TsDAVO), the SBU archive in Volyn Region, and the State Archive of Volyn Region (DAVO) and the State Archive of Rivne Region. Specifically, they are used to examine the question of an order by the leadership of the UPA and the OUN to murder Poles in Volhynia in 1943. This paper offers an estimate of Polish casualties derived from analysis of OUN-UPA, Polish, and Soviet sources and demographic data.

The issue of the mass murder of Poles by the Ukrainian Insurgent Army and the Bandera faction of the Organization of Ukrainian Nationalists is not only historical but also political. It concerns both policies by the Ukrainian and Polish governments concerning the classification of these events and the politics of historical memory concerning this case of political violence and their perpetrators in Ukraine and Poland, especially after the "Orange Revolution" in 2004 and the "Euromaidan" in Ukraine in 2014.

The Polish Senate and Sejm in 2013 declared the massacre of Poles in Volhynia as ethnic cleansing with features of genocide. The resolution adopted by the Sejm in 2016 declared the massacres of Poles in Volhynia and Galicia by the OUN and the UPA a genocide and proclaimed July 11 as the National Day of Remembrance of the Victims of the Genocide. The resolution by the lower chamber of the Polish parliament stated that "as a result of the genocide perpetrated in 1943-1945, more than 100,000 citizens of the Second Republic were murdered, mainly peasants. ${ }^{2}$

In contrast, the different Ukrainian governments referred to the Volhynia massacre as a "tragedy" involving mass killings of both Poles and Ukrainians. After the "Orange Revolution" and especially after the "Euromaidan," the OUN and the UPA and their leaders and members are 
officially treated as national heroes by the governments in Ukraine. President Yushchenko awarded posthumously the Hero of Ukraine title to Roman Shukhevych, the Supreme Commander of the UPA, and to Stepan Bandera, the leader of the main faction of the OUN (OUN-B), respectively in 2007 and 2010. These awards were condemned by the leaders of Poland and Russia, the European Parliament, and the Simon Wiesenthal Centre in the United States. President Poroshenko after the Euromaidan made the "Glory to Ukraine! Glory to the Heroes!" greeting of the Bandera faction of the OUN the official greeting of the Ukrainian Armed Forces and the Ukrainian police. He also made the OUN-B anthem the official song of the Ukrainian Army. The Ukrainian parliament pronounced the OUN and the UPA members as fighters for Ukrainian independence and made public disrespect towards members of these organizations by Ukrainians and foreign citizens a crime. Another law declared all OUN and UPA members, including those who were not rehabilitated because of their participation in the mass murder of Poles, the Nazi genocide, and other mass killings, as war veterans and made them eligible for government benefits. The governments of Poland, Israel, and Russia condemned such policies in Ukraine.

Under President Zelensky, there was no radical shift in the official stance on the Volhynia massacre and the OUN and the UPA overall, although he and his Servant of People party were less vocal on these issues, compared to Yushchenko and Poroshenko. Zelensky occasionally used the "Glory to Ukraine" greeting and stated that Stepan Bandera was a hero to a part of Ukrainians and that this was normal and "cool," because he "defended freedom of Ukraine." ${ }^{3}$ The regional and local administrations and governments in Western Ukraine, especially in Galicia, and to a lesser extent in some other regions of Ukraine, such as Kyiv city, 
continued to honor the leaders and members of the OUN and the UPA by opening their monuments, naming streets after them, and displaying the red and black flag of the OUN-B.

The government Institute of National Memory in Ukraine after the "Euromaidan," especially during the Poroshenko presidency, propagated the policy of the OUN and the UPA as national heroes and denied responsibility of these far right organizations for the mass murder of the Poles in Volhynia and Galicia. This government institute was headed during that time period by Volodymyr Viatrovych, who previously headed an OUN-B linked center in Lviv in Galicia. Viatrovych lacked peer-reviewed publications but used his position in this government agency in charge of historical memory policy to propagate such policies concerning the Volhynia massacre and the OUN and the UPA by means of issuing directives and propaganda materials to government officials, education institutions, and the mass media in Ukraine. In contrast, The government Institute of National Remembrance in Poland advanced the policy that branded the Volhynia massacre as a genocide perpetrated by the OUN-B and the UPA.

The Ukrainian media, in particular, television channels, such as $1+1,5$ th Channel and Priamyi, both of which are owned by Poroshenko, newspapers and magazines, such as Den, Dzerkalo tyzhnia, and Tyzhden, and online publications, such as Ukrainska pravda, including its historical section (Istorychna pravda), generally denied, ignored, downplayed or justified the mass murder of Poles by the OUN-B and the UPA. The media in Ukraine mostly presented these far right historical organizations, their members, and leaders as fighters for the Ukrainian independence and as national heroes. Research by Western, Polish, and some Ukrainian scholars that showed mass murder of the Poles by the OUN-B and the UPA was de facto censored in Ukraine after the "Euromaidan." 
The issue of the mass murder of Poles by the OUN-B and the UPA also became politically important because of involvement of the radical nationalist organizations, such as the Right Sector and Svoboda, in the violent overthrow of the Ukrainian government by means of the Maidan massacre of the protesters and the police during the "Euromaidan" in 2014 and their involvement in the Odesa massacre and the civil war in Donbas. These organizations regard the OUN and the UPA as their ideological predecessors and adopted their symbols, such as the "Glory to Ukraine" greeting. They played a crucial role in these crucial political events, in particular, by forming paramilitary formations and relying on violence. The far right successors of the OUN and the UPA and related radical nationalist and neo-Nazi organizations and their armed formations attained a significant role in the Ukrainian politics and ability to overthrow the Ukrainian government because of their use of violence and threat of violence. ${ }^{4}$ (See Katchanovski, 2016, 2020).

The KIIS Survey in 2009 showed that 35\% of the respondents in Ukraine believed that the OUN-B and the UPA were involved in the mass murder of Ukrainians, Poles, or Jews in the 1940s, while $1 \%$ believed that the OUN-B and the UPA only murdered Poles. However, in Volhynia and Galicia in Western Ukraine only, respectively, 14 and 15\%) said that the OUN-B and the UPA were involved in the mass murder of Ukrainians, Poles, or Jews in the 1940s, while $2 \%$ in both these regions said that the murders involved only Poles. Half (52\%) of the residents in Galicia and 28\% in Volhynia denied that the OUN-B and the UPA were involved in mass murder of Poles in the 1940s. (See Katchanovski, 2015a). Conversely, A 2008 Public Opinion Research Center poll in Poland found that just 5\% of Poles attributed "crimes" that were committed in Volhynia in 1943 to the UPA and Ukrainian nationalists, while 14\% blamed 
Ukrainians. But 19\% erroneously singled out Russians, the Soviet Union, Stalin, and NKVD as perpetrators of the crimes in Volhynia under the Nazi occupation in 1943. (Public, 2009).

The various poll results do not show a radical change of attitudes towards the OUN, the UPA, and their leaders and commanders since the "Euromaidan" in spite of the Ukrainian governments pro-OUN and UPA historical memory policy and propaganda and the incorporation

of their symbols, such as the "Glory to Ukraine" greeting by the military and leaders of Ukraine. The Razumkov Center poll in 2019 showed that $30 \%$ of the respondents in Ukraine viewed Stepan Bandera positively, compared to $20 \%$ in the 2004 Razumkov Center poll and $19 \%$ in the KIIS poll in 2013. Conversely, 32\% of the respondents viewed the OUN-B leader negatively in 2019, compared to 35\% in 2014. The actual attitude change is less significant because the 2019 poll excluded the Russian-annexed Crimea and separatist-controlled part of Donbas. These two regions had the lowest support for the OUN-B, the UPA, and Bandera and Shukhevych before 2014. (See Katchanovski, 2014, 2015).

\section{Previous Studies}

The number of previous academic studies of the Volhynia massacre in the West is very limited. Historical studies by McBride (2016) and Rudling (2012), call it the ethnic cleansing of the Poles on OUN-B and UPA orders. In contrast, Piotrowski (2000) calls it a genocide. Snyder (1999) calls ethnic cleansing not only the mass murder of Poles in Volhynia but also forced resettlement by the communist Polish government of Ukrainians from Poland to Soviet Ukraine and within Poland in operation "Wisla," primarily in 1944-1947. A similar approach to the forced resettlement of Ukrainians is offered by Subtelny (2001). 
The previous studies by Western scholars also link the mass murder of the Poles to experience of collaboration of the OUN and many UPA commanders and members in the Nazi genocide in Ukraine, Poland, and Belarus. (See Katchanovski, 2019, Rudling, 2020). For instance, at least 66 percent of 119 top OUN-B leaders and UPA and commanders in Ukraine served in police, militia, and local administration, the Nachtigall and Roland Battalions, the SS Galicia Division, Bergbauern-Hilfe (the Sushko Legion), studied in German or Germansponsored military and intelligence schools, or collaborated with intelligence and security agencies of Nazi Germany, primarily at the beginning of the Second World War. At least 42 percent of the top OUN-B and UPA leaders and commanders served in the auxiliary local police, the Schutzmannschaft Battalion 201, militia, police or militia schools, and other police and quasi-police formations. At least 78 percent of the top UPA commanders and 66 percent of middle-ranked commanders collaborated with Nazi Germany, in particular, at least 58 and 49 percent, respectively served in police or militia in the German-occupied Ukraine, Poland, and Belarus. (Katchanovski, 2019).

The absolute majority of the UPA members at least until the end of 1943 were policemen, who on OUN-B orders in spring of 1943 deserted the Nazi service and formed the basis of the UPA in Volhynia. These police commanders and members were typically involved in the Nazi genocide of Jews, Poles, Belarusians, and Russians. In particular, they participated, usually in assisting roles, in massacres of the Jews, Poles, and Ukrainians and in the mass murder of Soviet POWs. Nazi policy is universally classified by scholars as genocide because it envisioned and largely implemented complete annihilation of Jews. Since the Nazi policy also envisioned, for instance in 'Generalplan Ost,' and partly succeeded in a physical elimination of a significant parts of Belarusians, Poles, Russians, Ukrainians, and Roma, it also fits definitions of 
genocide by the UN Genocide Convention and many researchers of genocide. (See

Katchanovski, 2010, 2019).

In Poland, the mass murder of Poles in Volhynia has been often presented by historical researchers as genocide perpetrated by the OUN and the UPA, or more generally by Ukrainian nationalists or even Ukrainians. (See Filar, 1999; Motyka, 2011; Siemaszko and Siemaszko, 2000). The Polish studies often cite OUN-B and UPA orders to annihilate entire Polish population in Western Ukraine as a key evidence of the genocide. In particular, they refer to such orders mentioned in the Yuri Stelmashchuk's prosecution case, Stelmashchuk's letter to Mykola Lebed, and a number of other archival documents from Ukraine. The analysis presented in the next section of this paper suggests that versions of these orders quoted by many researchers cannot be considered as exact rendering of the order or orders to murder Poles. Furthermore, some these archival sources are misquoted or quoted selectively to advance them as key evidence of genocide.

In contrast, Volodymyr Viatrovych, the director of the main archive of SBU during Yushchenko's presidency and the head of the Institute of National Memory in 2014-2019, argued that no documentary confirmations of the existence of the order to exterminate the Poles has been found. He maintained that the key protocol of the Stelmashchuk's interrogation on February 28, 1945 never existed and that an excerpt from this protocol was fabricated by the KGB because the Stelmashchuk's criminal archival case did not contain this protocol. (Viatrovych, 2011, p. 93; 2012, pp. 112-120). However, this paper presents a copy of this protocol from the same HDA SBU archive and other evidence confirming that this was an authentic document and that such an order existed. 
Viatrovych (2011, p. 93; 2012, pp. 112-120) also claimed that the other versions of the killing directive cited by Polish researchers did not exist, because a fund in the SBU archives of Volyn Region contained documents from an entirely different case. However, Ukrainianlanguage versions these documents were published by Nakonechnyi (2006, pp. 116-117) with reference to the same archival funds. Information provided by the SBU archive in Volyn Region confirmed that Vladyslav Nakonechnyi, who served as the director the Soviet Communist Party archives in Volyn Region in the Soviet times and headed a regional commission tasked with historical research on World War II and Soviet political repressions, had access to such documents. But these archival documents could not be accessed by the author, because they either became classified again or were burned during the collapse of the Soviet Union in $1991 .{ }^{5}$

In Ukraine, a minority of researchers but many politicians from the Communist Party and the Party of Regions shared the view that the mass murder of Poles was genocide ${ }^{6}$. (See, for example, Nakonechnyi, 2006). In contrast, many Ukrainian historians and politicians presented the massacres as a part of a mutual Ukrainian-Polish conflict or war. They argued that this armed conflict started during World War II with killings of Ukrainians in the Chelm region of Nazioccupied Poland in 1942 and that it was caused by the policies of the Polish government in the period after World War I and before World War II when Volhynia was a part of Poland. They include discriminatory policies of pacification, settlement of osadniki and the land ownership. The UPA is presented as a large nationalist guerrilla army which enjoyed popular support and fought with the Armia Krajowa (AK) to defend the Ukrainian population in Volhynia from Polish attacks. An existence of an OUN-B or UPA order to conduct mass murder of Poles is often denied or disputed. (See, for example, Ukraina-Polshcha, 1998-2001; Viatrovych, 2011). 
There is no consensus concerning the number of Polish and Ukrainian casualties of the conflict. Ukrainian researchers often minimize the Polish casualties and inflate Ukrainian casualties, specifically by including victims of mass killings by Polish-dominated police and quasi-police formations, such as self-defense units, which acted on German orders.

Polish researchers generally estimate Polish casualties in Volhynia at 40-60 thousand and their total number, including Galicia and other regions, at 100-130 thousand. (Hrytsiuk, 2001, p. 262; Siemaszko, 2010, p. 94). However, such estimates are inflated because of the unwarranted extrapolation of the casualties from the known locations of the mass murders of Poles to locations where information about murders of Poles is lacking, or where no or very small number of Poles lived. These estimates are also inflated because of the inclusion of victims of other nationalist formations, the Ukrainian police, the Ukrainian Self-Defense Legion $\left(31^{\text {st }}\right.$ SiPo Battalion), the SS Galicia Division, unidentified "Ukrainians," and even pro-Soviet militia. Similarly, the demographic estimates of the casualties underestimate the excessive deaths and other losses linked to German genocidal policies and the number of Poles drafted into the Polish Army in 1944-45 (Hrytsiuk, 2001, pp 258-268; Katchanovski, 2019; Sprava 12).

Ukrainian historical researchers and the media often claimed that the "Glory to Ukraine! Glory to the Heroes!" preceded their use by the OUN-B and the UPA and was used by some Ukrainian military formations after Ukraine proclaimed independence from the Russian Empire in 1918. However, such claims are not confirmed by archival and other documentary sources, and there is no other contemporaneous evidence of use of the greeting in such form and as a greeting and not just as the "Glory to Ukraine" phrase. These claims are based primarily on a fictional novel published in the 1930 s, i.e. after similar greetings were adopted by the Nazi party and other fascist and semi-fascist parties, by a Ukrainian refugee, who would become a 
Nazi collaborator during World War Two. Archival documents and scholarly studies show that the "Glory to Ukraine! Glory to the Heroes!" greeting along with a fascist style hand salute were modeled by the OUN-B on a basis of similar greetings and salutes by other fascist and semifascist parties, such as the National Socialist German Workers Party in Germany, the National Fascist Party in Italy, and Ustasha party in Croatia. (See Katchanovski, 2014, 2015).

An order by an UPA commander in the Rivne Region on September 1, 1943, to stop using the fascist-style hand salute suggests that the hand salute, which was officially adopted by the OUN-B in April 1941, was also initially used by the UPA, in particular, during the height of its ethnic cleansing in Volhynia in summer 1943. The order stated to prohibit the hand salute of "extending the right arm, as it was done before" (Litopys, 2007, p. 317). It is noteworthy that this order was included in the UPA commander's order concerning distribution of land of ethnically cleansed Poles. ${ }^{7}$

\section{The Ethnic Cleansing of Poles in Volhynia}

Analysis of archival documents, historical studies, memories and testimonies of participants and eyewitnesses, shows that the mass murder of Poles in Volhynia was initiated and conducted by the Bandera faction of the OUN and the UPA, which was formed in this region by the OUN-B in spring 1943. Analysis of the same sources suggests that the killings turned into a systematic, large-scale and organized campaign of mass murder following a specific order or a number of related orders by the leadership of the OUN-B, the UPA, or their Security Service (SB).

A protocol of interrogation of Yuri Stelmashchuk, commander of the UPA district “Turiv," on February 28, 1945 states that Dmytro Kliachkivsky ("Klym Savur"), the commander 
of the UPA and the head of the OUN-B in North-Western Ukrainian Lands (PZUZ) gave him in June 1943 such a secret oral directive from the OUN-B central leadership (Provid). ${ }^{8}$ This document specifies that the order concerned "physical extermination of the entire Polish population that lived in the western regions of Ukraine." (See Photo 1).

[Photo 1 about here]

However, the Soviet interrogation protocol cannot be reliable source for the exact wording of this order. Stelmashchuk's testimony, like typically, testimonies of other such prisoners, was not recorded verbatim. It was translated from Ukrainian and written down in Russian in condensed form by the NKVD interrogators.

This interrogation protocol mentions a similar OUN-B oral order, passed by Kliachkivsky via SB, which acted as the Security Service of both OUN-B and the UPA, concerning annihilation of all Soviet prisoners of war. Other such OUN-B order given via SB channels concerned killings of all family members of suspected Soviet sympathizers. The protocol also mentions a similar directive of the central leadership of the OUN-B passed via the UPA line of command concerning elimination of all Russian UPA members under the guise of sending them to "Russian legions." 9 The analysis of archival documents, historical studies, memories and testimonies of participants and eyewitnesses, corroborates that the UPA and SB and conducted systematic killings of Soviet POWs, pro-Soviet sympathizers, including their families, and Russians serving in the UPA. (See Photo 1 and 2).

Materials of the Stelmashchuk's criminal prosecution case corroborate an existence of an order to murder Poles. But it is unlikely that the order pertained not only to Volhynia but to entire Western Ukraine, because the UPA was not formed at that time in other regions of Western Ukraine. The materials of the brief court hearing of his case note a Stelmashchuk's 
admission that he got the order from Kliachkivsky to destroy all Poles in the Kovel districts in June 1943 after he was appointed as the commander of the UPA detachment "Ozero" which operated primarily in Northern part of Volyn Region (Sprava 67424, pp. 94-95).

The absence of the 28 February 1945 interrogation protocol in the materials of Stelmashchuk's criminal archival case does not constitute a proof that it was falsified. Interrogation protocols were often not included in such files, for example if the arrested refused to confess or if protocols were used in other investigative cases or referred to higher authorities. The author of this study located a 1963 copy of this protocol in the electronic archive of HDA SBU. Another official copy of the same protocol of interrogation of Stelmashchuk was declassified and published in Russia in a collection of archival documents on the OUN. It contained notations by NKVD General Gorshkov that were dated by April 24, 1945. (Ukrainskie, 2012, pp. 578-581).

The information provided Stelmashchuk in the February 28, 1945 protocol at other protocols is generally directly or indirectly corroborated by other sources. For example, detailed information provided by Stelmashchuk in the protocol of his interrogation on 9 February 1945 concerning the location of Kliachkivsky allowed the Soviet NKVD within a few days to find and kill the commander of the UPA-North. (Litopys UPA, Vol. 9, 2009, pp. 430-437; Ukrainskie, 2012, pp. 567-568).

There is another version of this order purportedly recorded in a letter from Stelmashchuk to Mykola Lebed, then a member of the OUN-B central leadership (Nakonechnyi, 2006, pp. 116117):

Friend Ruban! I bring to your attention that in June, "Klym Savur," the representative of the central leadership of the OUN and the commander of the UPA-North, gave me an oral and secret directive regarding total and widespread physical destruction of the Polish 
population living on the territory of oblast ... For the implementation of this directive, I request carefully prepare for these actions and assign those responsible:" Lysyi", the UPA battalion commander in the Transbug districts; "Sosenko" in Turiisk, Ovadno and Oziutychi districts, "Golubenko " in Kovel county. "Glory to Ukraine!" "Rudyi." The commander of the UPA group "Turiv," June 24, 1943.

This version was published by Nakonechnyi (2006, p. 126) with a reference to the same collection of the SBU archives in Volyn Region. The same document was often quoted in Polish translation by Wladyslaw Filar and other scholars. But it is noteworthy that its Polish-language variant did not include the words ("living on the territory of oblast") after the "directive regarding total and widespread physical destruction of the Polish population." (See Filar, 1999, p 37; Motyka, 2011, p. 130).

The information concerning the killing order and the specific UPA commanders assigned such tasks is consistent with Stelmashchuk testimony and testimonies of other UPA members and local witnesses in the materials of his criminal case file (Litopys UPA, Vol. 9, pp. 429-472; Sprava 67424). But the titles of Klyachkivsky ("Klym Savur”) and Stelmashchuk ("Rudyi”) listed in this document correspond to their titles as of the end of 1943. In addition to other possible explanations of this disparity which might put in question a reliability of this document, it is also possible that the document did not contain the original letter, but its later Russian translation with the commanding titles changed. The examination of the original archival document would be important to deal with this problem, But as noted, this and other documents from this archival collection are either nor longer accessible to academic researchers or they were destroyed.

There is also a 1955 testimony by Zbigniew Kaminski, a SB OUN activist who was arrested in communist Poland. This document stated that the leadership of the OUN-B issued in 1943 a decree "concerning the mass liquidation of the Polish population, first in Polissia and 
Volhynia" and that later this "action" extended to other areas. Kaminski refers to Lebed as being responsible for this order as the head of SB. (Polska i Ukraina, 2005, pp. 180-198). However, Mykola Arsenych formally replaced Lebed as the head of the security service of the OUN since 1941. But Lebed headed the central leadership of the OUN-B until spring of 1943, and he remained a member of the OUN-B Provid afterwards.

At the OUN-B congress in August 1943, Roman Shukhevych, who became the leader of the OUN-B in spring 1943 endorsed along with most other members of the OUN leadership the policy of the mass extermination of Poles in Volhynia. In his speech in July 1944 at the founding meeting of the Ukrainian Supreme Liberation Council (UHVR), Shukhevych, who also became the Supreme Commander of the UPA, confirmed that the liquidation of the Polish population began in Volhynia in 1943 and that it ended in the summer of 1943. He stated that in Galicia the UPA leadership issued an order to evict Poles, unless they would themselves resettle (Litopys Ukrainskoi, Vol. 26, p. 490).

Another published document, which contains an order concerning the liquidation of all Polish men between 16 and 60 years old after retreat of German troops from villages, is often dated by June 1943 (Nakonechnyi, 2006, p. 116). Its Polish translation is often published in a distorted form with term the "Polish population" instead of "Polish men." (See, for example, Filar, 1999, p. 36). However, the reference in this order to the retreat of German troops and the almost identical document dated by May 30, 1944 suggest that this order more likely refers to 1944 and concerns primarily Galicia. (See Kutovyi, 2013). German troops retreated from most of Volhynia by spring 1944.

The existence of the unwritten order or several related orders by the OUN-B, the UPA, and SB concerning the extermination of Poles in Volhynia in summer of 1943 is confirmed directly 
or indirectly by other archival documents, including reports by the OUN-B, the UPA, the German occupational authorities, and Soviet partisans in Volhynia and testimonies of arrested UPA members and commanders.

For example, the instruction of SB in the collection of OUN-B documents in the State Archives of Volyn Region contains a directive to exterminate Poles utmost in "a wise way." Similarly, it calls to liquidate all those harboring Poles and other aliens, and kill all communist sympathizers, thieves, uncertain strangers, drunkards, secret informers, and other such groups deemed undesirable or suspect by SB, the OUN, and the UPA. The instruction also specifies killings of Jews discovered hiding in villages. (See Photo 2).

This instruction was most likely issued in summer 1943, since many of its clauses described basic functions of SB following the formation of the UPA, for instance, the requirement to salute commanders of the UPA. In addition, a clause concerning relations with the Melnyk faction of the OUN(OUN-M) in this document corresponded to a move from tactical cooperation with such units to their forced incorporation into the UPA in Volhynia in July 1943. It is noteworthy that this SB instruction has not been published in 100 volumes of old and new series of UPA Litopys and other collections of OUN and UPA documents (See, for example, Litopys UPA, Vol. 1-22, 1995-2013).

[Photo 2 about here]

Testimonies by Oleksander Lutsky and Mykhailo Stepaniak, members of the OUN-B and UPA leadership, confirmed an existence of the order to murder the Poles in Volhynia in 1943. Protocols of their interrogations state that this was a Kliachkivsky's initiative. (See Litopys UPA, Vol. 9, 2007). 
The most massive and widespread killings of Poles were conducted in Volyn Region shortly after the meeting of the regional leadership of OUN-B in PZUZ and Volyn in the beginning of July 1943 near the villages of Yaroslavychi and Yalovychi. These neighboring villages were situated on the border of Rivne and Volyn Regions close. The timing of the meeting, its location and the participants suggest that its agenda likely included the mass killing of the Poles in the region.

The analysis of memoirs of Danylo Shumuk and Stepan Semeniuk, participants of this OUN-B meeting, indicates that it took place after the raid by a Sydir Kovpak-led large detachment of Soviet partisans through Malyn on June 30, 1943 and the killings of more than 600, primarily Czech and Ukrainian residents of Malyn. The meeting ended before the killing of dozens of Ukrainian residents and partial burning of Yaroslavychi, Yalovychi, Velyka Horodnytsia, Mala Horodnytsia, and Vorsyn on July 13-14, 1943. These massacres were conducted by a German detachment with assistance police, which likely was partly Polish. This OUN-B meeting was attended by Dmytro Kliachkivsky. Other participants included Rostyslav Voloshyn, a member of the central leadership of the OUN-B, Oleksander Lutsky, representative of the main Provid of the OUN-B, Vasyl Makar, the head of SB in PZUZ, and Panas Matviichuk, the OUN-B leader in Volodymyr-Volynskyi district, who was appointed at that meeting as the OUN leader in the region (See Semeniuk, 2010, pp. 53-54; Shumuk, 1998, pp. 120-121).

Stepan Yanishevsky, who commanded SB in the "Zahrava" district of the UPA, which included most of Rivne Region and southern districts of Belarus near Pinsk, testified during his interrogation that SB under his command actively participated in the mass extermination of the Polish population and the destruction and burning of Polish settlements. The interrogation protocol specified that such a directive came from the main OUN-B Provid and the OUN-B 
leadership in PZUZ. It noted that Ivan Lytvynchuk, the UPA commander of "Zahrava" and the OUN-B leader in the region, was one of the initiators and active organizers of the mass killings of the Poles and burnings of their settlements. (Polska i Ukraina, 2005, p. 398). Yanishevsky's testimony, in particular, the reference to the leading role of Ivan Lytvynchuk ("Dubovyi"), in the extermination of Poles in this region, is confirmed by an UPA report issued by Lytvynchuk himself, This report described the massacre of more than 500 Polish residents of Huta Stepanska and 26 destruction of other Polish colonies, villages and hamlets in its vicinity on July 17-19, 1943 (Litopys UPA, Vol. 2, pp. 171-176).

Similar evidence concerning such an order to liquidate the Polish settlements is contained in testimonies of lower ranked UPA commanders in Volhynia, for example, Stepan Koval's testimony. He commanded the UPA detachment "Kotlovyna," which was based primarily in the southeastern part of Volyn Region. His testimony describes the order of the OUN-B in June 1943 concerning the destruction of Polish settlements in the whole region. He received such an order to destroy specific Polish settlements from Mykola Kovtoniuk Yakymchuk ("Oleg"), who was then the commander of the "Turiv" district of the UPA and a leader of the OUN-B in Volyn Region. (Litopys UPA, Vol. 15, pp. 570-730). Members of the Koval's UPA unit and Oleksii Brys (“Ostap"), a UPA commander in the Volodymyr-Volynskyi area in Volyn Region also testified that such an order was issued and it was was implemented by the UPA units in the area. (See Litopys UPA, Vol. 15, pp. 577-607, 657-672; Sprava 75175FP; Sprava 8054FP, p. 64).

Testimonies of Polish and Ukrainian witnesses and interrogations of UPA commanders and members, who participated in the attacks, corroborate independently one from another organized destruction by the UPA detachment under the command Koval at least two dozen 
Polish settlements in the area between Lutsk, Tsuman, Kolky, and Kivertsi, and killings of more than 500 their residents at the beginning of July 1943. These settlements included Oleksandria, Marianivka, and Vulka Kotovska. (See, for example, Litopys UPA, Vol. 15, pp. 570-730; Siemaszko and Siemaszko, 2000).

The same concerns for the murder of about 4 thousand Poles and mass burning of Polish settlements in Kovel and Liuboml counties and nearby areas at the end of August 1943 by the UPA detachment "Ozero" and SB units. These actions included massacres of the Polish residents of Volia Osrovetska and Ostrovky. Similarly, the UPA detachments of "Sich" and SB units murdered more than 5 thousand Poles and burned almost 100 settlements, including Pavlivka, Zagai, and Kyselyn, in Volodymyr-Volynskyi and Khorokhiv counties, primarily in the first half of July 1943 (See Siemaszko and Siemaszko, 2000; Sprava 118, pp. 55-57). Similar massacres of the Polish residents and destruction of the large numbers of their settlements were conducted by the UPA and SB in other parts of Volyn Region, in Rivne Region, including Kremenets County, in summer 1943.

While mass killing of the Poles in Volhynia by the OUN-B, the UPA and SB was organized and large-scale, this mass murder cannot be classified as genocide based on most academic definitions of genocide. The same applies to the definition of genocide set out in the UN Genocide Convention. There is no evidence of the intent of the OUN-B and the UPA to eliminate entire or a significant part of the Polish nation. The analysis shows that the order or more likely a number of related orders issues by the OUN-B, the UPA, and SB, aimed primarily at a physical elimination of the entire or significant part of the Polish minority in Volhynia. But these actions were limited to a relatively small region with a relatively small ethnically Polish population. The total number of Poles in Volhynia in 1942 was about 300 thousand. The same is 
true of Galicia where the OUN-B, the UPA, and SB conducted mass killings of Poles in 1944. While still significant, these killings were on a relatively smaller scale, compared to neighboring Volhynia.

The figure of about 35 thousand Poles killed by the UPA and SB throughout Volhynia in 1943 is a more reliable than much higher estimates of around 60 thousand. This estimate is derived and corroborated by a number of methods. The figure of 38.6 thousand documented Polish casualties attributed in Siemaszko (2010) to the OUN-B, the UPA, and SB and other nationalist formations in 1939-1948 in Volhynia is adjusted to excludes victims of formations that were under German services, such as the Ukrainian police, the 31 SiPo Battalion, unidentified "Ukrainians," and those killed before and after 1943. Instead of unwarranted extrapolation of the casualties from the known locations of the killings of Poles to locations where information about the murders of Poles is lacking, the estimate of the numbers of likely undocumented casualties adjusted for documented casualties in unknown locations is used. The estimate of around 35-40 thousand casualties is also obtained through analysis of demographic changes of the Polish population in Hrytsiuk (2001, pp. 258-268) with adjustments for undercounted excessive deaths and other losses linked to German genocidal policies and for the numbers of Poles drafted into the Polish Army in 1944-45.

The estimate of 20 thousand documented Polish casualties of the UPA and the Ukrainian police in Volyn Region in 1943, after making similar adjustments, is close to the figure of 15 thousand Poles murdered by the UPA in this region in the testimony of Yuri Stelmashchuk (Siemaszko and Siemaszko, 2000, 1045; Sprava 67424, p. 89). The same concerns a 26 thousand casualty figure, primarily, based on Soviet archival documents, after adjusting it for overestimation of the number of Poles killed in many large-scale massacres, such as in Volia 
Ostrovetska, Ostrivky, and after excluding more than 600 casualties in Opalyn, because they were Jewish victims of the Nazi genocide. (See Nakonechnyi, 2006, pp. 117-118).

The 35 thousand Poles killed in Volhynia in 1943 by the OUN-B, the UPA, and their security service is an approximate estimate because data used in these calculations are subject to an error. However, such estimation errors are unlikely to change the relative magnitude of the mass murder of Poles. A significant proportion (some 12\%) of ethnic Poles in Volhynia was killed. But the Polish casualties comprised about $1 \%$ of the pre-war population of Poles in territories where the UPA was active and $0.2 \%$ of the Polish population in Ukraine and Poland.

The UPA and SB only did not have the capacity to eliminate the entire Polish population in Volhynia. The documents captured by the Soviet NKVD from Kliachkivsky following his killing, indicate that the total strength of units of the UPA and SB in this region at the beginning of 1944 was about 5 thousand people (Litopys UPA, Vol. 14, pp. 70-79). The UPA and SB units often had to resort to forceful mobilization of local Ukrainian residents in neighboring villages to be able to attack and liquidate entire Polish settlements or their large parts. The UPA and SB, with some exceptions, did not control towns, cities, and pliatsuvky with large Polish population.

The mass killings by the UPA and SB forced a much greater number of Poles to leave their settlements and move to pliatsuvky, such as Przebraze (now Haiove), to towns and cities controlled by Germans in Volhynia, or to other regions, such as Galicia and Chelm. Many Polish settlements in Volhynia were burned by the UPA and SB during the massacres and after all or most of their inhabitants left. This makes it more compatible to a definition of ethnic cleansing and cases of ethnic cleansing in Bosnia, Croatia and Kosovo in the 1990s which also included the massacres of ethnic minorities. 
The analysis of various sources shows that the mass murder of the Poles in Volhynia in 1943 was primarily one-sided ethnic cleansing organized by the OUN-B, the UPA and SB and not a mutual Ukrainian-Polish conflict. The AK in Volhynia was much weaker compared to the UPA in summer 1943, and it was not able to prevent or stop most of the massacres of the Polish population or burning of their settlements. AK units were involved in many attacks on Ukrainian villages and murdering their Ukrainian residents. But the scale and the magnitude of these murders of Ukrainians in the region by the AK was not comparable to the murders of Poles by the UPA and SB.

The largest mass killings of Ukrainians, for instance in Sahryn by the AK, and in Verkhovyny (Wierzchowiny) by the National Armed Forces (NSZ), were in the Chelm area and other areas of the Lublin Region in 1944-1945. The massacre of about 700 Ukrainian residents of Sahryn was perpetrated in March 1944 by the AK as a collective "retribution" after massacres of Polish residents in nearby Korchunky and Edwardopol villages in Volhynia and in Huta Pieniacka in Galicia. (See Jasiak, 2001). However, the massacres of Poles in Korchunky and Edwardopol were perpetrated by the $31^{\text {st }}$ SiPo battalion, which was jointly organized by the German SD and the OUN-M. The massacre in Huta Pieniacka was perpetrated by the police regiments of the SS Galicia division with UPA unit support. (Katchanovski, 2014, 2019). These massacres of the Poles by collaborationist formations were a part of the Nazi genocidal policy. The murdered Ukrainian residents of Sahryn, including children and women, were not responsible for the actions of the UPA.

Similarly, the massacre of Ukrainian residents of Verkhovyny by the National Armed Forces (NSZ) in the Chelm area in 1945 was not a part of the armed conflict with the UPA. The mass killing of ethnic Ukrainians in Verkhovyny and other murders of Ukrainians in these Polish 
regions by the far right NSZ were a part of ethnic cleansing aimed at forcing out Ukrainians, who did not want to leave during the forced resettlement of local Ukrainians by the communist government of Poland. ${ }^{10}$ (See Zajączkowski, 2006). This massacre and related killings coincided with mass forced resettlement of the Ukrainians in the Chelm and other border regions of Poland to Soviet Ukraine as a part of agreement between the Polish and Soviet governments in 1944 of the forced exchange of the Ukrainian and Polish populations. These forced resettlements and the Operation "Wisla" in 1945 also constituted the ethnic cleansing, but they were not a UkrainianPolish war or genocide.

The specific estimate of Ukrainian casualties of the AK and other such Polish formations in Volhynia in 1943 is difficult to make because of lack of systematic and reliable data and because in many cases the perpetrators are identified only as Poles. But the analysis shows that biggest cases of mass killings attributed to Poles in Volhynia were in fact perpetrated by Polishdominated police and quasi-police formations, such as self-defense units subordinated to the German authorities. For example, this concerns massacres of Ukrainians in the villages of Krasnyi Sad, Zapillia, Zvozy, and Slovatychi in 1943 by Poles from such police or self-defense units, which were under the command of the German gendarmerie and other German agencies. (See, for example, Polska i Ukraina, 2005, pp. 689-698, 796-803; Sprava 56, p. 119). These mass killings of Ukrainians by the Polish-dominated police and self-defense units, which were generally formed or deployed to Volhynia in spring and summer of 1943, were a part of the Nazi-led genocide. However, many of these police and quasi-police formations in Volhynia were under de factor control of the AK, and a significant proportion of their members defected and joined the AK and NSZ at the end of 1943 and the beginning of 1944. 
Similarly, the OUN had de facto control of most local police and quasi-police formations in Volhynia from the start of the German occupation till spring 1943. These units, most of whose members joined the UPA, mainly, in spring 1943, assisted in the mass murder of Jews, Ukrainians, Poles, and Russians among the civilian population and Soviet POWs. The majority of commanders and members of the UPA and SB in Volhynia in 1943 were former policemen who participated in the Nazi genocide. They included most of the top UPA and SB commanders in Volhynia, in particular, Stelmashchuk, Lutsky, Kovtoniuk-Yakymchuk, Koval, Yanishevsky, Ivan Klymchak ("Lysyi”), and Porfyrii Antoniuk ("Sosenko"). The police units, whose commanders and/or significant proportion of members or joined the UPA in 1943, participated in mass murder of up to 23 thousand Jews in Rivne, 19 thousand in Lutsk, 19 thousand in Volodymyr-Volynskyi, 18 thousand in Kovel, 14 thousand in Sarny, 13 thousand in Dubno, 8 thousand in Kremenets, and 10 thousand in Ostroh in 1941-1943. Such police commanders and units also assisted in Nazi-led executions of some 3 thousand Ukrainians in Kortelisy, more than 130 Ukrainian residents of Klubochyn, and some 50 Poles Oborky in fall of 1942. (See Katchanovski, 2019).

\section{Conclusion}

The mass murder of the Poles in Volhynia in 1943 became an important political issue in Poland and Ukraine after the collapse of communism, and especially after the "Orange Revolution" and the "Euromaidan" in Ukraine. Previous studies by Polish, Ukrainian, and Western researchers suggest different and often divergent theories of this historical event. This paper shows that this mass murder was organized and carried out by the OUN-B, the UPA, and 
their security service. The analysis of various sources shows that there was an order or more likely a series of related orders concerning the mass killing of Poles in Volhynia.

This study concludes that the mass murder of the Polish minority in Volhynia represented not a Ukrainian-Polish war or genocide of Poles but that it was a part of an ethnic cleansing by the OUN-B, the UPA, and their security service (SB). These killings of the Polish civilian population by the armed units of the UPA like subsequent mass killings of Ukrainian civilians in Volhynia and Poland by the armed units of the AK and NSZ were not a war by two armed forces. Relatively less numerous killings of Poles in Galicia in Western Ukraine by the OUN and the UPA and Ukrainians in Chelm Region and neighboring border regions of Poland by the far right NSZ and less violent forced resettlements of Ukrainians by the Polish communist government also constituted ethnic cleansings.

The mass murder of Poles in Volhynia cannot be classified as genocide because there is no evidence of the intent of the OUN-B and the UPA to eliminate entire or a significant part of the Polish nation. Estimated 35 thousand Pols were killed by the UPA and SB in Volhynia in 1943. A significant proportion of the ethnic Poles in Volhynia became victims. But the number of killed comprised a relatively small proportion of ethnic Poles population in Ukraine or Poland.

The OUN-B and UPA-led mass murder campaign against the Polish minority in Volhynia in 1943 was a part of ethnic cleansing. The mass killings were combined with destructions of most Polish settlements. They led to much greater numbers of Poles being driven from their homes. The UPA and SB had relatively small membership, and they did not control the absolute majority of towns, cities, and plyatsuvkas with sizable Polish population. From a theoretical and comparative perspective, this conflict was similar to ethnic cleansings in Bosnia, Kosovo, and Croatia in the 1990s. 


\section{References}

Filar, Władysław. (1999). Eksterminacja Ludności Polskiej na Wołyniu w Drugiej Wojnie Swiatowej. Warszawa.

Hrytsiuk, Grzegorz. (2001). "Vtraty naselennia na Volyni u 1941-1944rr.” Ukraina-Polshcha: Vazhki Pytannia, Vol. 5. Warsaw: Tyrsa, pp. 249-70.

Jasiak, Marek. (2001). “Overcoming Ukrainian Resistance: The Deportation of Ukrainians within Poland in 1947.” In Redrawing Nations: Ethnic Cleansing in East-Central Europe, 1944-1948, Philipp Ther and Ana Siljak (Eds.). Lanham, Md.: Rowman \& Littlefield, 173-194.

Katchanovski, Ivan. (2020). "The far right, the Euromaidan, and the Maidan massacre in Ukraine.” Journal of Labor and Society, 23, (1), 5-29.

Katchanovski, Ivan. (2019). "The OUN, the UPA, and the Nazi Genocide in Ukraine." In Mittäterschaft in Osteuropa im Zweiten Weltkrieg und im Holocaust / Collaboration in Eastern Europe during World War II and the Holocaust. Peter Black, Béla Rásky, and Marianne Windsperger (Eds.). New academic press, Vienna, pp 67-93.

Katchanovski, Ivan. (2016). "The Far Right in Ukraine During the "Euromaidan" and the War in Donbas.” Paper presented at the Annual Meeting of the American Political Science Association, Philadelphia, September 1-4, https://papers.ssrn.com/sol3/papers.cfm?abstract_id=2832203.

Katchanovski, Ivan. (2015a). "Terrorists or National Heroes? Politics and Perceptions of the OUN and the UPA in Ukraine." Communist and Post-Communist Studies 48 (2-3).

Katchanovski, Ivan. (2015b). "The "Snipers' Massacre” on the Maidan in Ukraine.” Paper presented at the Annual Meeting of the American Political Science Association, San 
Francisco, September 3-6, 2015, https://papers.ssrn.com/sol3/papers.cfm?abstract_id=2658245.

Katchanovski, Ivan. (2014). “The Politics of World War II in Contemporary Ukraine,” Journal of Slavic Military Studies, 27 (2), 210-233.

Katchanovski, Ivan. (2010). "Politics of Soviet and Nazi Genocides in Orange Ukraine." EuropeAsia Studies, 62 (6), 973-997.

Kutovyi, Roman. (2013). "Polityka OUN (B) shchodo polskoho naselennia Volyni v roky nimetsko-radianskoi viiny." $I i, 74$, http://www.ji.lviv.ua/n74texts/Kutovyj_Polityka_OUN.htm.

Litopys Ukrainskoi Povstanskoi Armii. Vol. 26. (2001). Lviv: Litopys UPA.

Litopys UPA. Vol. 1-22. (1995-2013). Kyiv: Institute of Ukrainian Archeography and Source Studies.

Litopys UPA. Vol. 11. (2007). Kyiv: Institute of Ukrainian Archeography and Source Studies. Marples, David R. (2007). Heroes and Villains: Creating National History in Contemporary Ukraine. Budapest: Central European University Press.

McBride, Jared. (2016). "Peasants into Perpetrators: The OUN-UPA and the Ethnic Cleansing of Volhynia, 1943-1944." Slavic Review, 75(3), 630-654.

Motyka, Grzegorz. (2011). Od rzezi wołyńskiej do akcji "Wisła": konflikt polsko-ukraiński, 1943-1947. Kraków: Wydawnictwo Literackie.

Nakonechnyii, Vladyslav. (2006). Volyn - Kryvave pole viiny. Ternopil: Pidruchnyky i posibnyky.

Piotrowski, Tadeusz. (2000). Genocide and rescue in Wolyn: Recollections of the Ukrainian nationalist ethnic cleansing campaign. Jefferson, NC: McFarland. 
Polska i Ukraina w latach trzydziestych-czterdziestych XX wieku. Nieznane dokumenty z archiwów stużb specjalnych. Vol. 4. Part 1. (2005). Warsaw.

Public Opinion Research Center. (2009). “Wolyn 1943.” http://www.cbos.pl.

Rudling, Per. A. (2020). "Rehearsal for Volhynia: Schutzmannschaft Battalion 201 and Hauptmann Roman Shukhevych in Occupied Belorussia, 1942.” East European Politics and Societies, 34(1), 158-193.

Rudling, Per Anders. (2012). “Warfare or War Criminality?” Ab Imperio 1, 356-381.

Semeniuk, Stepan. (2010). I hynuly pershymy. Lutsk: Teren.

Siemaszko, Ewa. (2010). “Bilans zbrodni,” Biuletyn Instytutu Pamięci Narodowej, 7-8: 77-94.

Siemaszko, Wladyslaw and Ewa Siemaszko. 2000. Ludobojstwo dokonane przez nacjonalistow ukrainskich na ludnosci polskiej Wolynia, 1939-1945. Warsaw: Borowiecky,

Shumuk, Danylo. (1998). Perezhyte i peredumane. Kyiv: Vudavnytstvo imeni Oleny Telihy.

Snyder, Timothy. (1999). ““To Resolve the Ukrainian Problem Once and for All”: The Ethnic Cleansing of Ukrainians in Poland, 1943-1947.” Journal of Cold War Studies, 1(2), 86120.

Sprava 6, Fond R-1021, Opys. 1. DAVO, Lutsk.

Sprava 12, Fond 582, Opys 11. TsDAVO, Kyiv.

Sprava 56, Fond R 2, Opys 2. DAVO, Lutsk

Sprava 118, Fond 3833, Opys 1. TsDAVO, Kyiv.

Sprava 372 Fond 13, Vol. 89. Electronic archive of HDA SBU, Kyiv.

Sprava 67424. HDA SBU, Kyiv.

Sprava 75175FP. HDA SBU, Kyiv.

Sprava 8054FP. Archive USBU in the Volyn Region, Lutsk. 
Subtelny, Orest. (2001). "Expulsion, Resettlement, Civil Strife: The Fate of Poland's Ukrainians, 1944-1947." In Redrawing Nations: Ethnic Cleansing in East-Central Europe, 19441948, Philipp Ther and Ana Siljak (Eds.). Lanham, Md.: Rowman \& Littlefield, 155-172. Ukraina-Polshcha: Vazhki Pytannia, Vol. 1-5. (1998-2001). Warsaw: Tyrsa.

Ukrainskie natsionalisticheskie organizatsii v gody Vtoroi mirovoi voiny. Dokumenty. Vol. 1, 2. 2012. Moscow: ROSSPEN.

Viatrovych, Volodymyr. (2012). Istoriia z hryfom “Sekretno.” Lviv: Chasopys.

Viatrovych, Volodymyr. (2011). Druha polsko-ukrainska viina. 1942-1947. Kyiv Kyiv Mohyla Akademy.

Zajączkowski, Mariusz. (2006). “Spór o Wierzchowiny. Działalność oddziałów Akcji Specjalnej NSZ w powiatach Chełm, Hrubieszów, Krasnystaw i Lubartów na tle konfliktu polskoukraińskiego (sierpień 1944 r. - czerwiec 1945 r.).” Pamięć i sprawiedliwość. 1(9), 265308. 


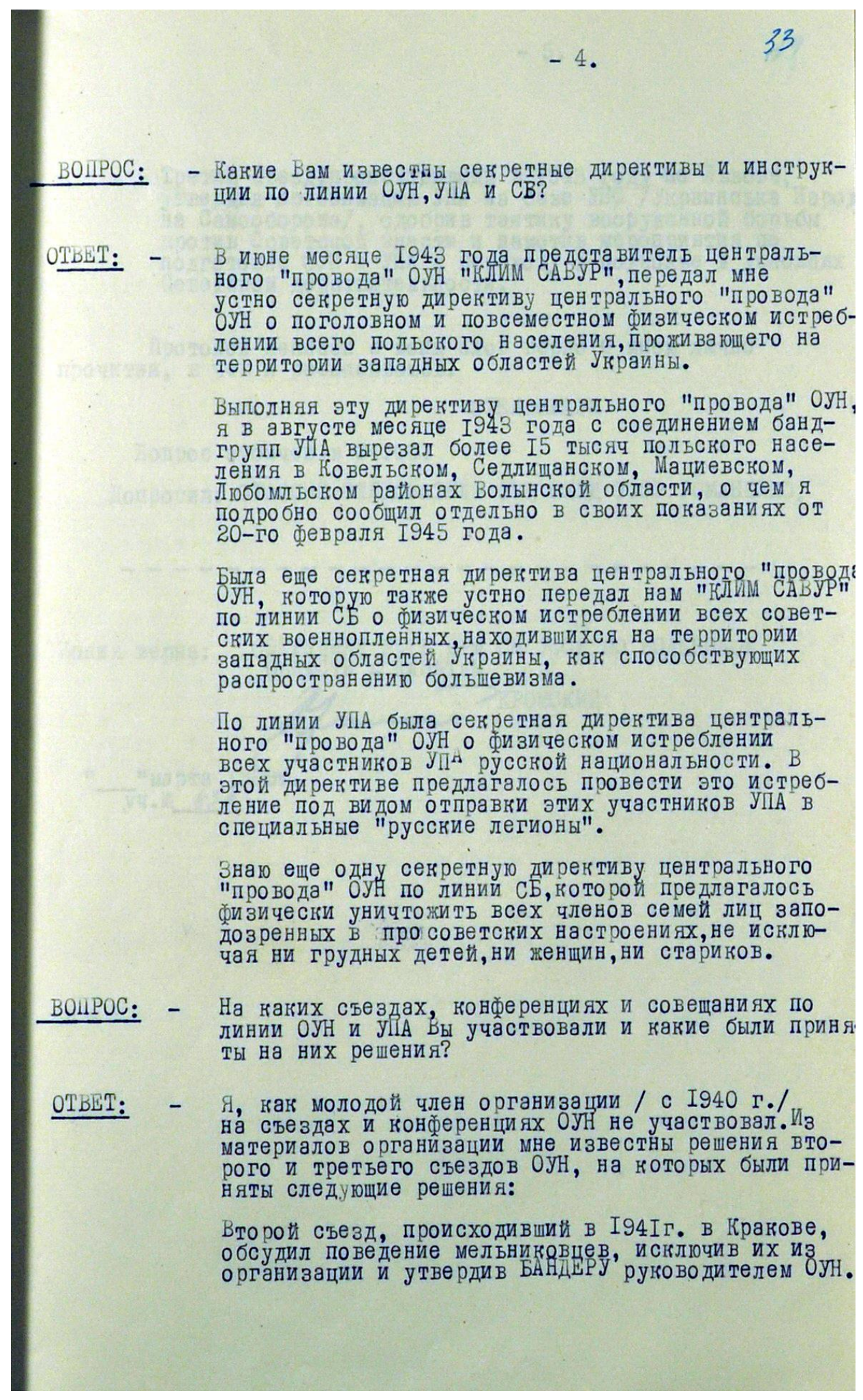

Photo 1. References to secret orders concerning mass murder of Poles, Soviet prisoners of war and other groups of people in a copy of the interrogation protocol of Yuri Stelmashchuk. Source: Sprava 372, Vol. 89, Ark. 33. 


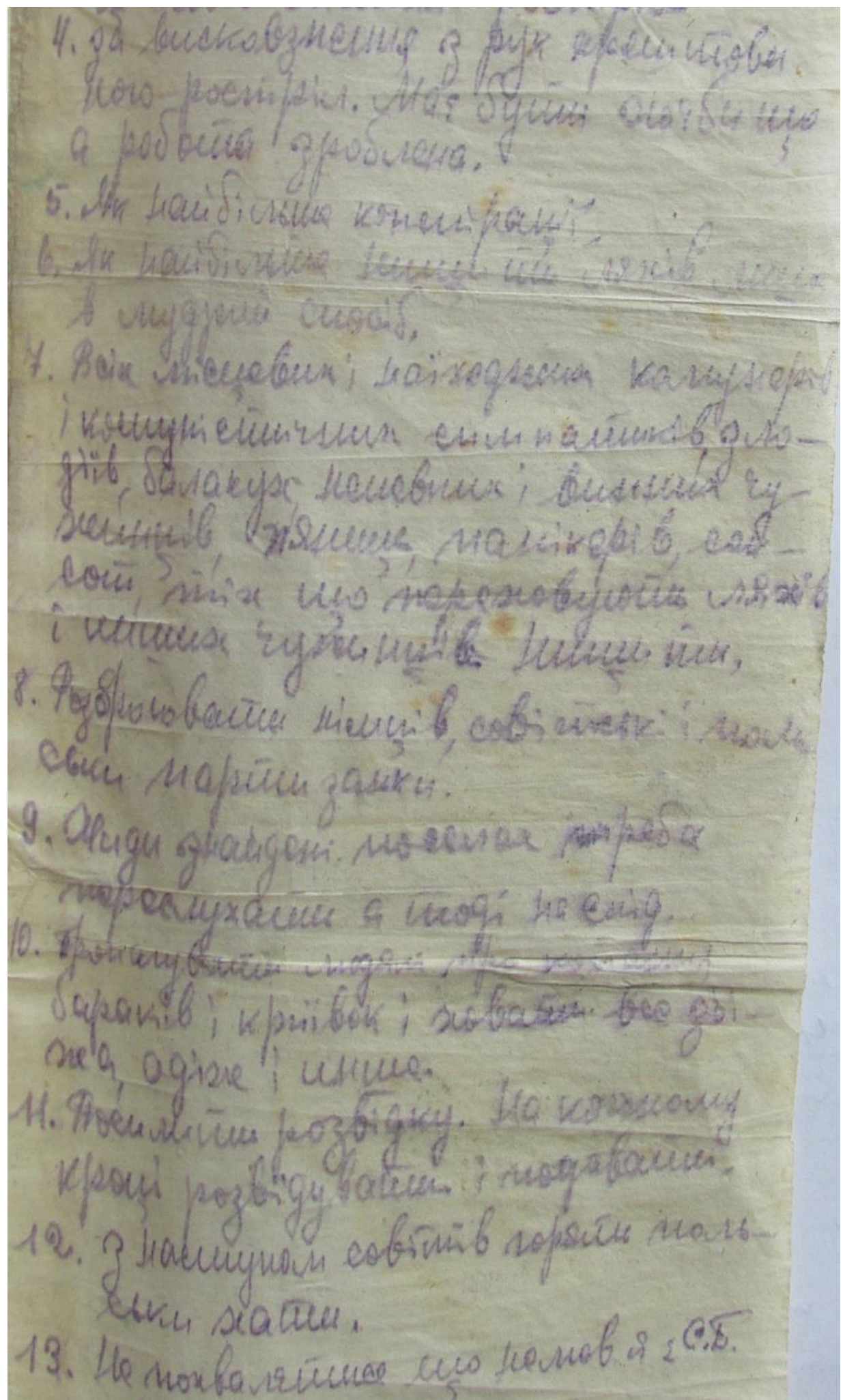

Photo 2. A part of the SB Instruction. Source: Sprava 6, ark. 53. 


\section{Notes}

${ }^{1}$ The earlier version of this paper was presented at the 19th Annual World Convention of the Association for the Study of Nationalities at Columbia University in New York in 2014.The earlier Ukrainian-language version of this paper was written for Istorychna pravda on invitation of its editor in July 2013, but it was not published for political reasons.

2 “Uchwała Sejmu Rzeczypospolitej Polskiej z dnia 22 lipca 2016 r. w sprawie oddania hołdu ofiarom ludobójstwa dokonanego przez nacjonalistów ukraińskich na obywatelach II Rzeczypospolitej Polskiej w latach 1943-1945," Sejm, http://orka.sejm.gov.pl/opinie8.nsf/nazwa/625_u/\$file/625_u.pdf.

3 “Зеленский о Бандере: для части украинцев он герой - и это классно,” BBC Ukrainian, 18 April 2019, https://www.bbc.com/ukrainian/features-russian-47974206.

${ }^{4}$ Svoboda controlled several important positions the Ukrainian government after the Maidan, and it headed regional governments in several regions, primarily in Western Ukraine. Although Pravyi sektor formally turned itself into a political party, it remained a paramilitary formation, which made it influential on the national and regional levels. Pravyi sektor attained de facto power in Volhynia in the immediate aftermath of the Yanukovych overthrow.

${ }^{5}$ Personal communication at the SBU archive in the Volyn Region.

${ }^{6}$ See, for instance, a 2013 letter by 148 members of the Ukrainian parliament, mainly from the Party of Regions and the Communists.

${ }^{7}$ I am grateful to Wieslaw Tokarczuk for bringing this order to my attention.

${ }^{8}$ This UPA district included the territory of Volyn Region and Ostrozhets distict of Rivne Region in Volhynia and the southern part of Brest Region in Belarus. 
${ }^{9}$ A small number of Russians, mainly Soviet prisoners of war who deserted various police formations or escaped from POWs camps, served in the UPA. Like a small number of Jews, Russians were in the UPA units mainly because they provided a relative protection from the Nazi genocide and because the UPA needed their specialized skills and knowledge.

${ }^{10}$ For instance, mother and grandparents of the author were forced to resettle from the Bezek village in the Chelm area to Volhynia in Soviet Ukraine in June 1945 right after a pregnant sister of the author's grandmother was killed and her small children were wounded in a nearby Polish village of Zingeruwka. She was killed in this Polish village, which was located near a gathering place of the NSZ unit right before it gathered its members there and moved to perpetrate the massacre in Verkhovyny (see Zajączkowski, 2006). 